\title{
Environmental quality research in the Beasley Lake watershed, 1995 to 2007: Succession from conventional to conservation practices
}

\author{
M.A. Locke, S.S. Knight, S. Smith Jr., R.F. Cullum, R.M. Zablotowicz, Y. Yuan, and R.L. Bingner
}

\begin{abstract}
The Beasley Lake watershed (BLW), established for the Mississippi Delta Management Systems Evaluation Area project, represents the US Mississippi Delta region in the national Conservation Effects Assessment Project. The 915-ha (2,260-ac) BLW drains into an oxbow lake that has been monitored since 1995 when row crops were grown on $79 \%$ of the area, and the remaining area included a $25-\mathrm{ha}(62-\mathrm{ac})$ lake and a 135-ha (330-ac) riparian forest. Currently, row crops account for $66.5 \%$ of the area with $12.4 \%$ enrolled in the Conservation Reserve Program. Cotton (Gossypium hirsutum L.) acreage has decreased from $63.3 \%$ to $8.9 \%$. Historical and current research in BLW focuses on monitoring lake limnology, evaluating conservation practice effects on edge-of-field runoff, quantifying changes associated with the Conservation Reserve Program, and modeling watershed responses. Applying combinations of conservation practices can significantly reduce nonpoint source pollution. For example, converting row crops to reduced tillage and transgenic herbicide-resistant crops in BLW reduced suspended sediment (70\% reduction), total phosphorus (41\% reduction), and pesticide concentrations in lake water. Corresponding increases in Secchi visibility (97\%) and chlorophyll $a$ (a primary productivity indicator) likely contributed to improved fish productivity (e.g., fish weight increase comparing 1998 and 2004: Micropterus salmoides 87\%, Lepomis macrochirus, 65\%) during this period. Additional studies should quantify effects of individual practices and improve modeling tools for making better management decisions. The utilization of the Annualized Agricultural Non-Point Source (AnnAGNPS) model and the Riparian Ecosystem Management Model (REMM) together provides additional information on the effectiveness of conservation practices within the watershed by combining technology that assesses riparian buffer effectiveness in filtering nutrients at the field scale with the watershed water quality transport capabilities of the AnnAGNPS model.
\end{abstract}

Key words: buffers-conservation-Conservation Effects Assessment Project (CEAP)ecosystem-nutrients - pesticide - soil-tillage — water quality-wetland

The Mississippi Delta region (figure 1) comprises $1.1 \times 10^{7}$ ha $\left(2.7 \times 10^{7} \mathrm{ac}\right)$ of the southern portion of the Mississippi River Alluvial Plain. The Delta region is a narrow band, widening in some places to approximately $160 \mathrm{~km}$ (100 mi) that extends over 1,100 km (688 mi) from southeastern Missouri to the Gulf of Mexico. Historically, cotton (Gossypium hirsutum L.) production dominated the rural and intensively agricultural region, but in recent decades, agriculture has diversified to soybean (Glycine max [L.] Merr.), rice (Oryza sativa), catfish (Ictalurus punctatus), and corn (Zea mays L.). The climate is classified as humid subtropical production, and resulting annual sediment losses of up to $16 \mathrm{t} \mathrm{ha}^{-1}\left(6.5 \mathrm{tn} \mathrm{ac}^{-1}\right)$ have been reported (Dendy 1981; Murphree and McGregor 1991). The warm, humid climate in this region is ideal for insects and weeds and requires the use of pesticides in agricultural production. Pesticide and nutrient loss in runoff is therefore another water quality concern in the delta (McDowell et al. 1984; Rebich 2004; Willis et al. 1983).

The original hypothesis for the Beasley Lake watershed (BLW) under the MDMSEA project was that implementation of physical structures combined with grassed field borders and filter strips would be sufficient to improve lake water quality. Studies subsequently determined that this was not always the case (Rebich and Knight 2001; Nett et al. 2004). Therefore, the current hypothesis for Conservation Effects Assessment Project (CEAP) research under Mississippi Delta conditions is that additional innovative management practices will improve lake water quality and fishery productivity. A general goal is to assess the effects of integrated conservation management practices on water quality and ecology. Specific objectives include (1) assessing the effectiveness of conservation practices to reduce contaminants and improve lake ecology; (2) evaluating the efficiency of vegetative buffers and Conservation Reserve Program (CRP) on edge-of-field runoff, ecology, and soil characteristics; and (3) utilizing models such as the Annualized Agricultural NonPoint Source (AnnAGNPS) model to assess the effects of management and water quality changes at the watershed scale. Smaller studies in the watershed, such as the use of constructed wetlands and vegetated ditches to mitigate contaminants, may serve as the basis for developing new research that will pro-

with an annual rainfall ranging from 1,140 to $1,520 \mathrm{~mm}$ (45 to $60 \mathrm{in}$ ) and temperatures averaging $18^{\circ} \mathrm{C}\left(64^{\circ} \mathrm{F}\right)$.

During the last two decades, concerns about the impacts of agriculture on water quality in the delta ultimately led to the establishment of the Mississippi Delta Management Systems Evaluation Area (MDMSEA) project (Locke 2004). Although the delta region topography averages less than $1 \%$ slope, significant quantities of sediment are lost in runoff from rainfall events common during spring and fall months. Multiple tillage operations have been a traditional and common component of delta row crop
Martin A. Locke is a soil scientist, Scott S. Knight is an ecologist, Sammie Smith Jr. is a chemist, and Robert F. Cullum is an agricultural engineer at the Water Quality and Ecology Research Unit, National Sedimentation Laboratory, USDA Agricultural Research Service (ARS), Oxford, Mississippi. Robert M.Zablotowicz is a microbiologist at the Southern Weed Science Research Unit, USDA ARS, Stoneville, Mississippi. Yongping Yuan is an agricultural engineer at the University of Mississippi, Oxford, Mississippi. Ronald L. Bingner is an agricultural engineer at the Water Quality and Ecology Research Unit, National Sedimentation Laboratory, USDA ARS, Oxford, Mississippi. 
vide needed data for the Riparian Ecosystem Management Model (REMM) (Lowrance et al. 2000) improvements.

This paper describes current research (2003 to 2007) in BLW and documents changes in the lake water ecosystem from 1995 to 2005 as BLW evolved from row crop agriculture dominated by cotton production to a mixture of row crop and non-cropped areas. Complementary studies that addressed field and edge-of-field practices also are discussed. Those studies and the overall watershed management database provide a comprehensive assessment of the impacts of integrated management of conservation practices on a watershed scale.

\section{Materials and Methods}

Site History and Description. The BLW (latitude $33^{\circ} 24^{\prime} 15$ and longitude $90^{\circ} 40^{\prime} 05$ ) is located in Sunflower County, Mississippi, and is part of the Big Sunflower River watershed (hydrologic unit code 08030207) within the Yazoo River Basin. The watershed has a total drainage area of approximately 915 ha $(2,260$ ac) and a 25 to 30 ha $(60$ to $75 \mathrm{ac})$ oxbow lake that was formed when a meander of the Big Sunflower River (figure 2) was isolated. The Big Sunflower River defines the northern part of the watershed boundary, and a large riparian forested wetland (125 to 145 ha [300 to $350 \mathrm{ac}]$ ) is located on the eastern side of the lake. As may be expected in an area adjacent to a meandering river with historical stream-floodplain interaction, soil texture varies from sandy loam to heavy clay. Soil survey data show that Dundee (fine-silty, mixed, thermic Typic Endoaqualfs), Forestdale (fine, smectitic, thermic Typic Endoaqualfs), Dowling (very-fine, smectitic, thermic Vertic Epiaquepts) and Alligator (very-fine, smectitic, thermic Alic Dystraquerts) are major soil series represented (figure 3). The difference in elevation from the top of the watershed boundary to the lowest point in the bottom

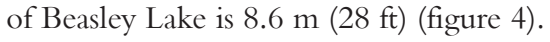

The focus of MD-MSEA research, including that in BLW, was to monitor changes in lake water quality as a function of management practice (Locke 2004; Rebich and Knight 2001). Edge-of-field structural and vegetative practices were established by MD-MSEA researchers in BLW from 1994 to 1996 (figure 1). Structural edge-of-field measures included slotted board risers and slotted inlets positioned in pipes at low points draining individual fields. Wooden boards

\section{Figure 1}

Mississippi Delta region of the United States.

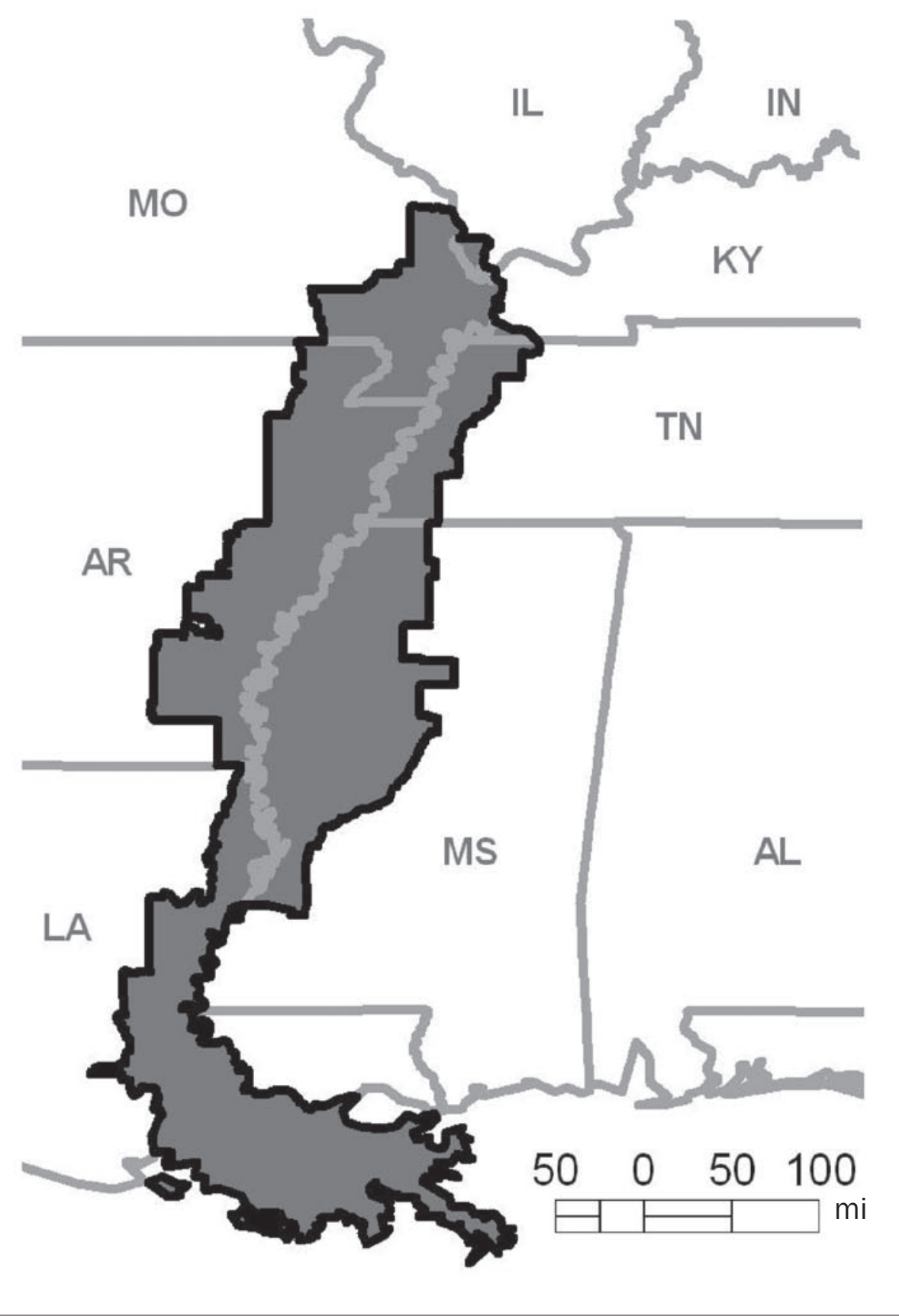

placed in slots at the pipe inlet impeded water flow, allowing sediment to settle at the pipe entrance. Vegetative measures included establishing or maintaining fescue (Festuca arundinacea Schreb.) and switchgrass (Panicum virgatum) buffers to slow runoff and help trap chemicals and sediment. Farm management decisions in BLW were at the discretion of the landowners or farmers, with exception of the edge-of-field measures described.
Lake Water Evaluations: Limnology. Lake water was sampled biweekly at three locations, and water samples were processed and evaluated for sediment, total organic carbon (TOC), chlorophyll, Secchi visibility, and nutrients (Knight et al. 2001a; Cooper et al. 2003; Cullum et al. 2003; Knight and Welch 2004). Data were compiled, and means were calculated to show water quality changes over time. Analytical and chemical 


\section{Figure 2}

Map of the Beasley Lake watershed showing sampling locations.

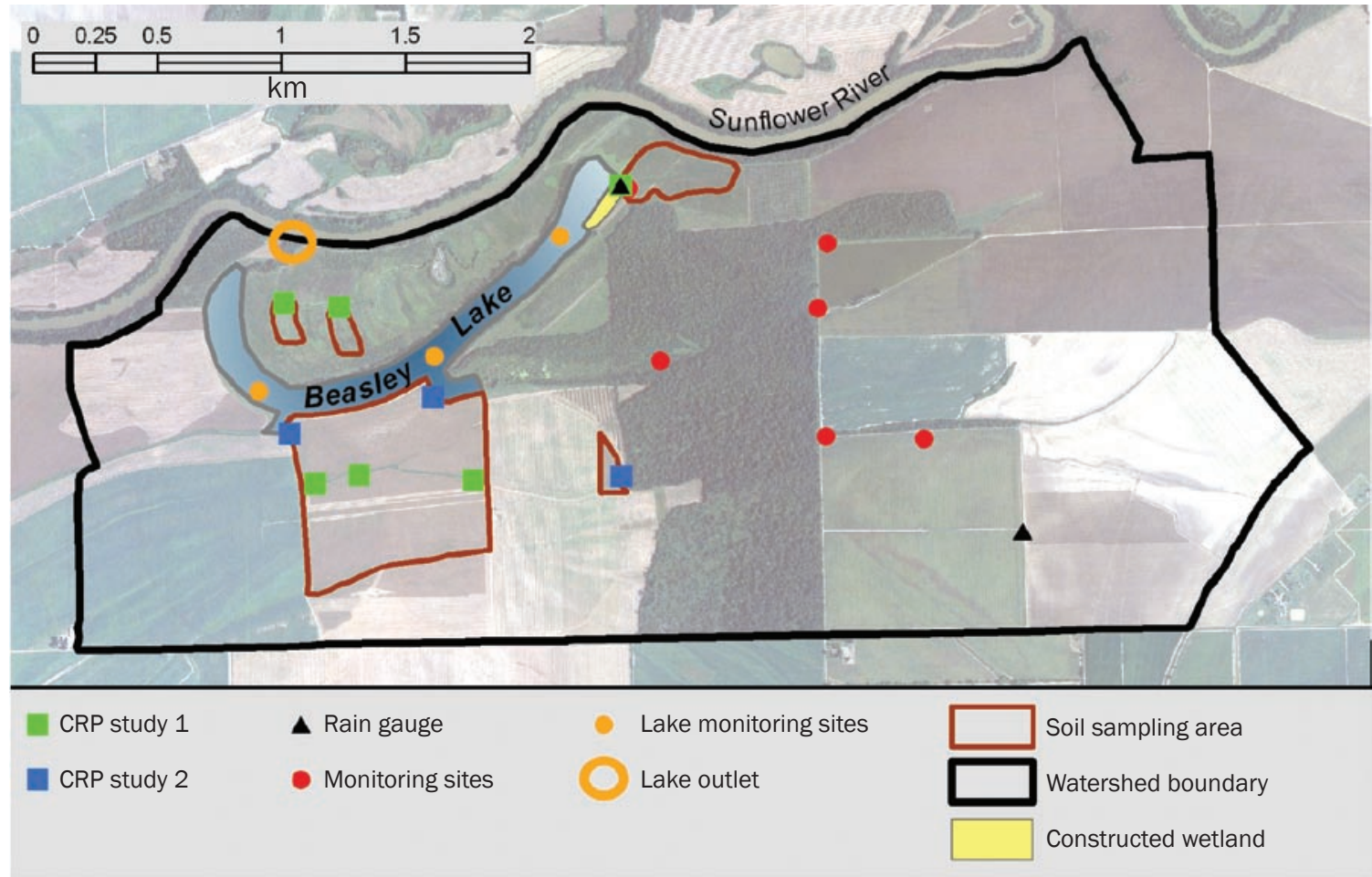

\section{Figure 3}

Soil survey map of the Beasley Lake watershed.

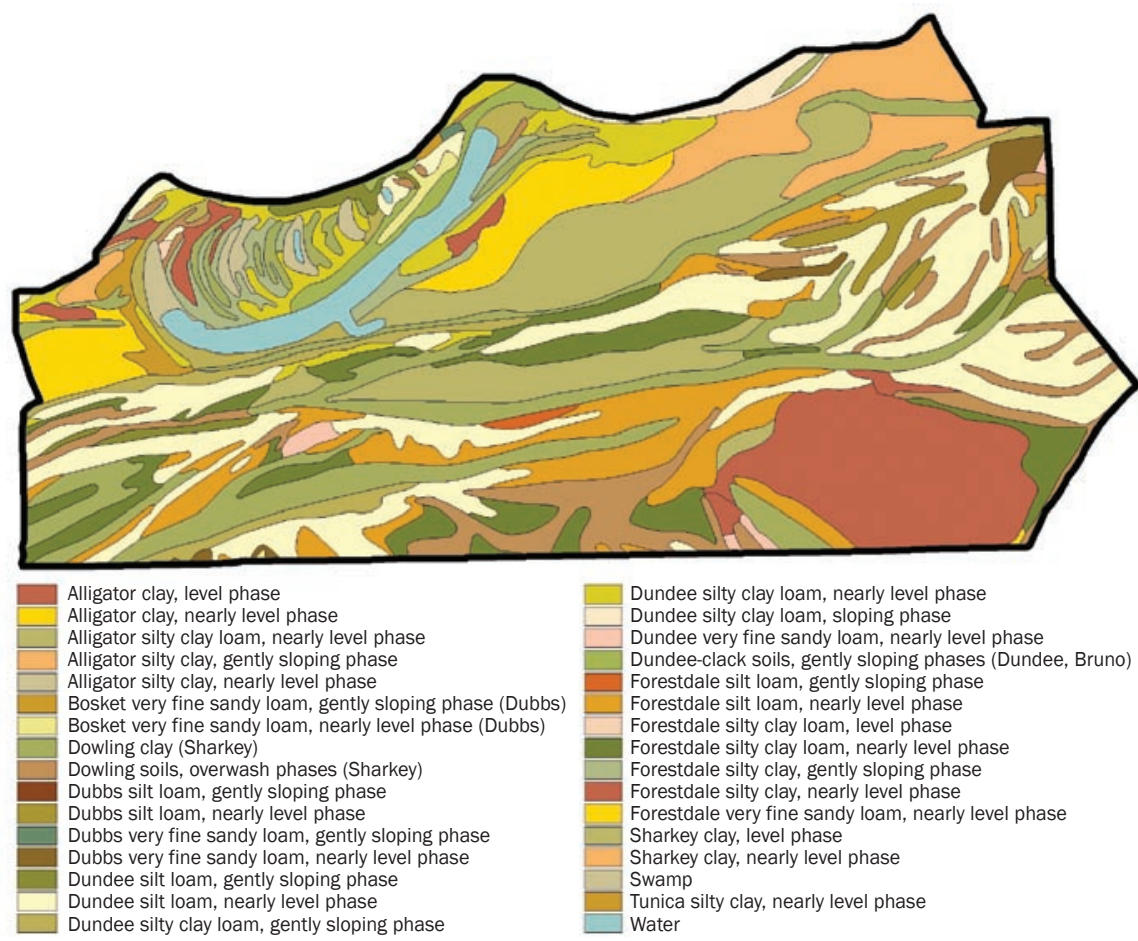

methods were based on procedures from the American Public Health Association (1992). Calculation of means and statistical analysis was done with SAS procedures (SAS Institute Inc.). All parameters were treated for differences at the $5 \%$ level of significance unless specifically stated otherwise.

Lake ecology was assessed by evaluating longer term fisheries indicators, e.g., Knight et al. 2001b. Prior to implementation of conservation practices, the existing community of fishes was eradicated using 5\% rotenone solution to remove pollution tolerant species and provide a competitive advantage for game fishes. A 3:1 mix of bluegill (Lepomis macrochirus) and redear sunfish (Lepomis microlophus) were stocked at a rate of 1,200 fingerlings ha $\mathrm{h}^{-1}\left(486 \mathrm{ac}^{-1}\right)$ together with 370 channel catfish (Ictalurus punctatus) fingerlings $\mathrm{ha}^{-1}\left(150 \mathrm{ac}^{-1}\right)$ in the fall of 1996. Largemouth bass (Micropterus salmoides) were introduced at a rate of 125 fingerlings ha ${ }^{-1}$ $\left(51 \mathrm{ac}^{-1}\right)$ in the spring of 1997. In 2002, a shoreline application of $2 \%$ rotenone was used to control gizzard shad (Dorosoma cepedianum) that were inadvertently introduced into the lake during the flooding of the adjacent Sunflower River in 1998 and 1999.

Fish were sampled in 1998 and 2004 


\section{Figure 4}

Map showing the topography (a) the entire Beasley Lake watershed and (b) Beasley Lake.

(a)

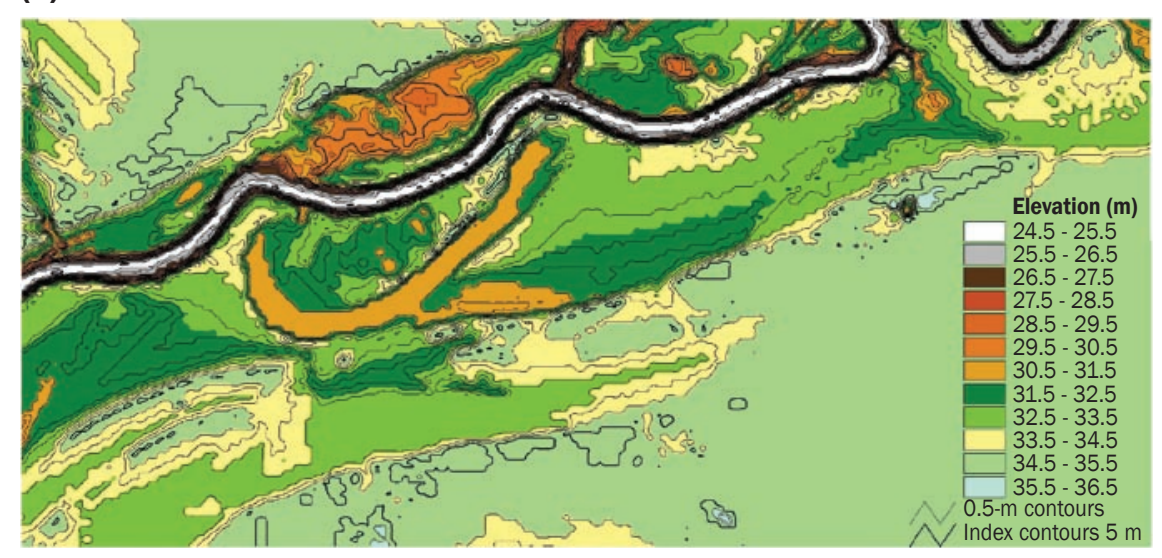

(b)

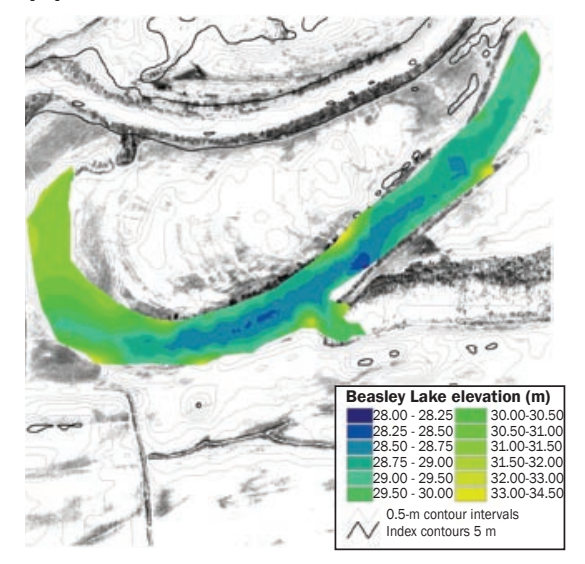

using a boat mounted Coffelt Model VVP2C electroshocker operating at 250 volts. Sampling effort was limited to no more than one hour of electrofishing time in order to provide adequate survey coverage while minimizing damage to recovering populations. Captured fish were placed in holding tanks until each could be weighed, measured for total length, identified to species, and released. Catch by numbers, weight and unit of effort were calculated.

Only a limited literature base is available on biochemical processes in oxbow lakes. Two enzymatic activities fluorescein diacetate (FDA) hydrolysis and alkaline phosphatase were assayed in monthly samples from February 2000 to December 2003 as bioindicators of lake microbial and planktonic activity. Fluorescein diacetate hydrolytic activity represents a total activity of general hydrolytic enzymes such as esterase, and lipase, and thus is a general indicator of total microbial activity. Fluorescein diac- etate hydrolysis has been used to determine water quality changes in freshwater creeks (Regel et al. 2002) and lake water infiltration into ground water (Miettenen et al. 1996). Alkaline phosphatase has been used as a component of assessing water quality in estuaries (Boyer 2006) and as an indicator of biotic integrity of streams (Hill et al. 2003). Other biological indicators assessed include total algae enumerated by most probable number analysis using Bristol's media, total bacteria as described by Zablotowicz et al. (2004), and chlorophyll a content. Several physical and chemical characteristics such as TOC, total solids, electrical conductivity, and $\mathrm{pH}$ were measured.

Fluorescein diacetate activity was determined according to Zablotowicz et al. (2004). Alkaline phosphatase activity was determined by adding $p$-nitrophenyl phosphate $(8.4 \mathrm{mg}$ in $1.0 \mathrm{~mL}$ of $\mathrm{pH} 11.0$ buffer to $10 \mathrm{~mL}$ of water with toluene, $250 \mu \mathrm{L}$ added to inhibit growth) and incubated for 24 hours.
Formation of $p$-nitrophenol was determined spectrophotometrically after adding $4 \mathrm{~mL}$ $(0.14 \mathrm{oz})$ of $0.5 \mathrm{~N} \mathrm{NaOH}$ to terminate the reaction and enhance detection of $p$-nitrophenol. Both assays were conducted at $28^{\circ} \mathrm{C}$ $\left(82^{\circ} \mathrm{F}\right)$ in triplicate with a no-substrate water sample incubation to correct for background interference. The $p$-nitrophenyl phosphate was added to the control blanks after adding the $\mathrm{NaOH}$.

Insecticides and Herbicides. For lake pesticide evaluations (1998 to 2005), 4-L (1.06-gal) water samples were collected monthly in triplicate. Samples were extracted on site by adding $4 \mathrm{~g} \mathrm{KCl}(0.14 \mathrm{oz})$ and 400 $\mathrm{mL}(14 \mathrm{oz})$ pesticide grade ethyl acetate and shaking for $1 \mathrm{~min}$. Samples were placed on ice, transported to the laboratory, stored at $4^{\circ} \mathrm{C}\left(39^{\circ} \mathrm{F}\right)$ (usually $\left.<72 \mathrm{~h}\right)$, and processed for pesticide analyses via gas chromatography using methods similar to those described elsewhere (Bennett et al. 2000; Smith and Cooper 2004; Smith et al. 2007). In separate analyses, fluometuron was determined by high-pressure liquid chromatography (samples from 1996 to 1999) and enzyme linked immuno-diffusion assay (samples from 2000 to 2003) as described by Zablotowicz et al. (2004, 2006).

Field and Wetland Evaluations: Wetland and Drainage Ditch Studies. In several individual BLW studies, wetlands and vegetated drainage ditches were assessed for their ability to improve water quality in agricultural runoff via sediment entrapment and agrichemical (pesticide and nutrient) retention, degradation, and processing. Details of this methodology are published elsewhere (Moore et al. 2001; Shankle et al. 2004; Weaver et al. 2004; Zablotowicz et al. 2001).

Edge-of-Field Conservation Management Effects on Quality of Water Leaving the Field. The hypothesis for edge-of-field assessments is that water quality improvement can be demonstrated via specific combinations of field management practices (Rebich 2004; Rebich and Knight 2001; Smith et al. 2002). Improvement in edge of field water quality is primarily based on the reduction of sediments, since many of the contaminants of interest entering the streams are attached to these particles. Runoff monitoring sites were established from 1995 to 1996 and monitored by the US Geologial Survey for the MDMSEA project from 1995 to 2003 (Rebich 2004). Most of these were discontinued in 


\section{Figure 5}

Distribution of management and use of land in the Beasley Lake watershed in (a) 1995, (b) 2000 , and (c) 2005 .

(a)

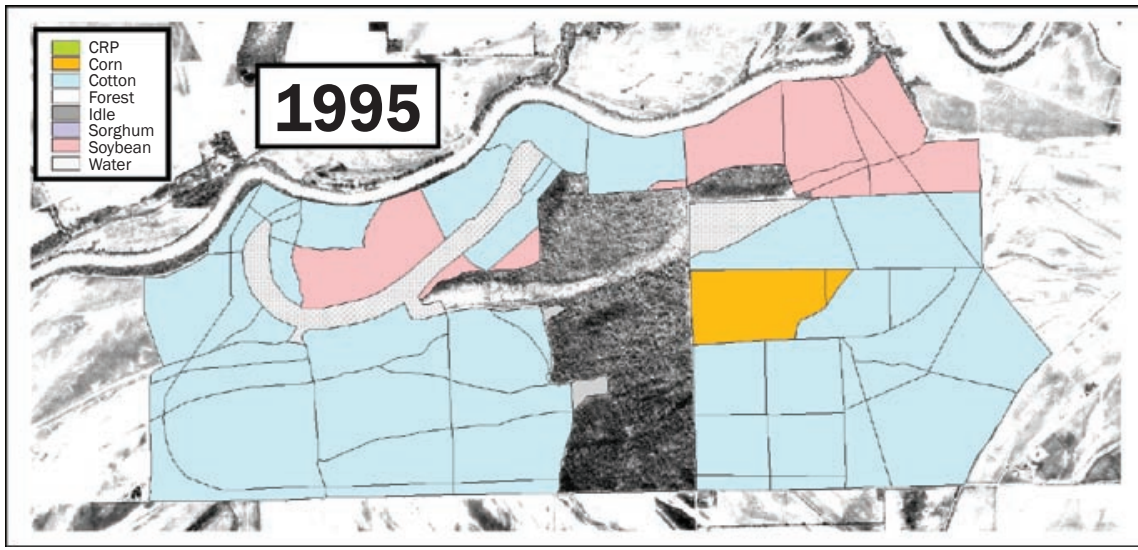

(b)

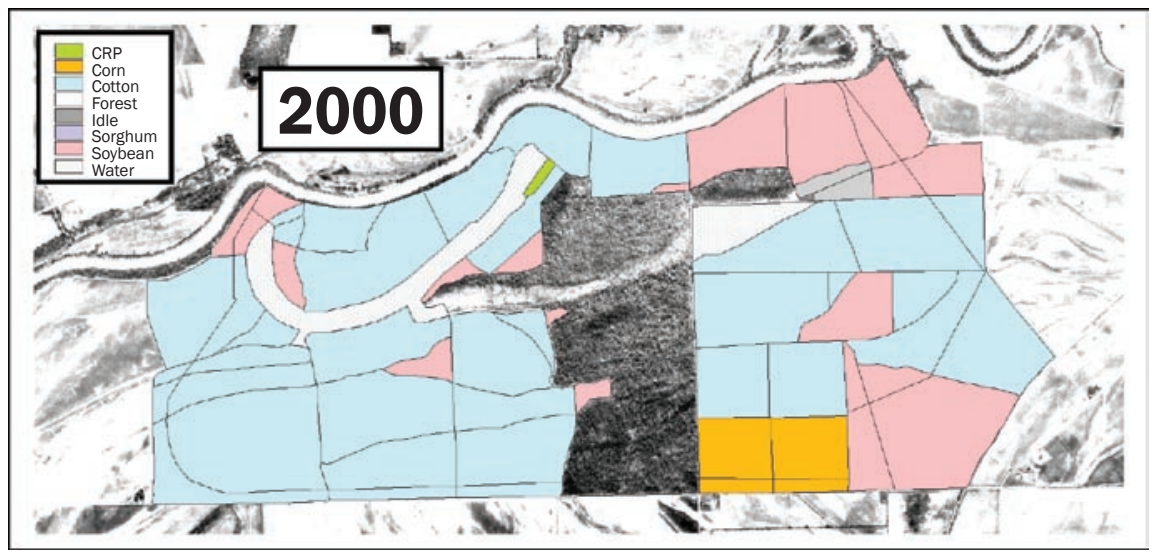

(c)

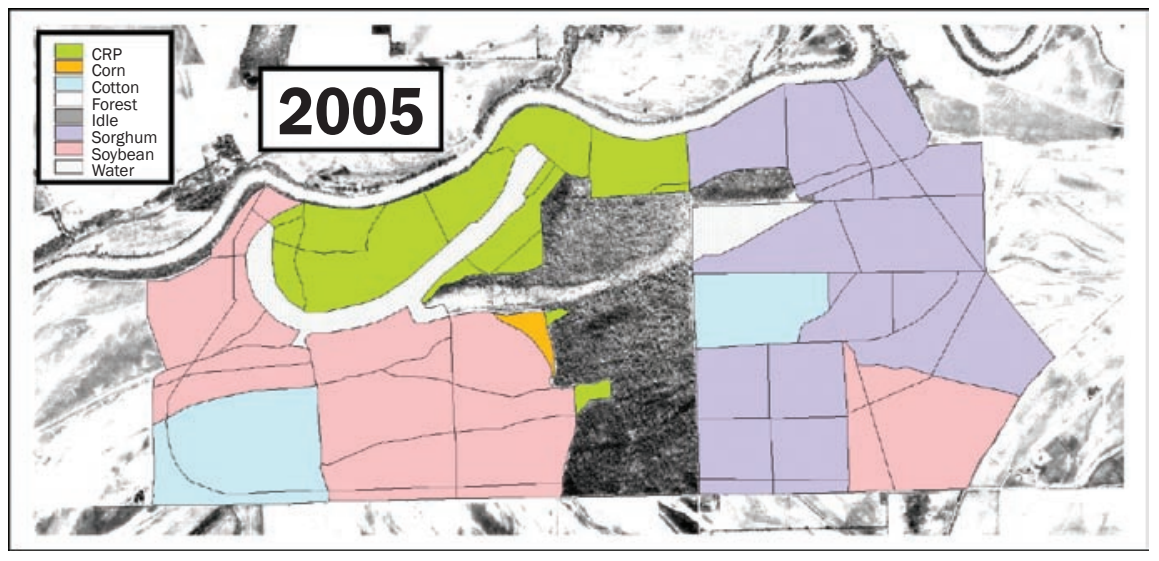

2003, but a few were continued to assist with CEAP research.

Sites with various edge-of-field management practices (e.g., slotted board risers, tile drainage, stiff grass hedges) were instrumented to sample runoff. Nutrient and pesticide analyses were conducted, and preliminary results are reported in Smith et al. (2002).

New CEAP research was initiated in 2006 using triplicate slotted-inlet pipe sites on both CRP and cropped land (Cullum and
Locke 2007). Approximately 12\% (113 ha [280 ac]) of the BLW was converted from cropped land to CRP beginning in 2003, and the remainder of the cropland is still managed for soybean, cotton, or corn production. Six subdrainage areas (1.2 to 6 ha [3 to $15 \mathrm{ac}$ ]) of similar topography and soil types were selected from either areas cropped in reduced tillage soybean (three sites) or areas planted in trees and set aside as CRP (three sites). Subdrainage areas were instrumented in September 2005 to collect water samples from field drainage slotted-inlet pipes during all surface runoff events. These runoff samples were analyzed for sediments, nutrients, and pesticides. Improvements in edge-of-field water quality will consist of evaluating differences in nutrient, pesticide, and sediment in runoff resulting from converting cropped land to CRP.

Agronomic Management Effects on Runoff. As part of the MD-MSEA project, a study was conducted from 1996 to 1999 to compare the insecticide concentrations in runoff samples from fields planted with or without Bacillus thuringiensis (Bt) cotton. Insecticides were applied to both Bt and non-Bt fields, but fewer applications and lower rates were applied in the Bt fields. Insecticides included various pyrethroid and organophosphate compounds typically used in the Mississippi Delta on cotton. Methods for analysis of insecticides in runoff were described in a previous section. Other details of the methodology used in this study are reported in Cullum and Smith (2001).

Soil Assessments. Prior soils research in BLW evaluated the spatial distribution of soil characteristics (Gaston et al. 2001) and their effects on herbicide dissipation (Locke et al. 2003) under conventional tillage cotton production. Other research demonstrated the effects of vegetative buffers on soil characteristics and potential implications for herbicide dissipation (Staddon et al. 2001).

Our current research is focused on assessing various physical and chemical parameters such as aggregate stability, soil organic carbon, and nutrient content following conversion of land from row crop to CRP. Subwatersheds under CRP versus non-CRP areas were surveyed in 2006, and soil (0 to $5 \mathrm{~cm}$ [0 to 2 in]) was sampled in a grid pattern and characterized. Land owners within the watershed are establishing quail habitat buffers around various fields. In future studies, soils in these buffer areas will be sampled and characterized 
prior to buffer establishment and monitored over time for any changes.

Modeling. The historical and current data collected from BLW provide vital information for evaluating the impact of conservation practices on water quality, although this is difficult to assess without the use of watershed models. A major contribution toward evaluating effective conservation planning for the watershed will be from the utilization of the AnnAGNPS model (Bingner and Theurer 2001).

The development of associated model input parameters, which includes watershed physical information, management information and climate information, are based on historical data collected that includes land management, and climate information. Management information, including various field management operations such as planting, cultivation, fertilization, pesticides and harvesting, has been monitored since 1995. A detailed elevation survey of watershed characteristics, including landscape features and channels, was conducted from 2005 to 2007. Runoff and sediment data collected from the monitored sites within the watershed were used to validate the model. According to the CEAP validation guidelines (Moriasi et al. 2007), the Nash-Sutcliffe coefficient of efficiency (E) (Nash and Sutcliffe 1970) can be used to evaluate the model's performance based on the ranges from minus infinity to one, with one indicating the model is perfect. Simulation results that produced values of $\mathrm{E}$ between 0.36 and 0.75 are considered satisfactory (Moriasi et al. 2007).

A validation of conditions present during 1996 to 2003 within the watershed was performed to estimate sediment transported within the watershed based on actual rainfall, land-use, and field management. Results from this simulation were used as a baseline or a reference for evaluating the effects of alternative conservation practices that included various tillage operations and/or land uses. Simulations of alternative agricultural management practices were compared with the baseline simulation to compare their effects on water quality within the watershed.

\section{Results and Discussion}

To assess conservation practice effects on water and soil quality in real farming systems, the MD-MSEA used a watershed-based systems approach where effects of watershed management in three oxbow lakes were com-

\section{Figure 6}

Phosphate and suspended sediment for Beasley Lake (1995 to 2005).

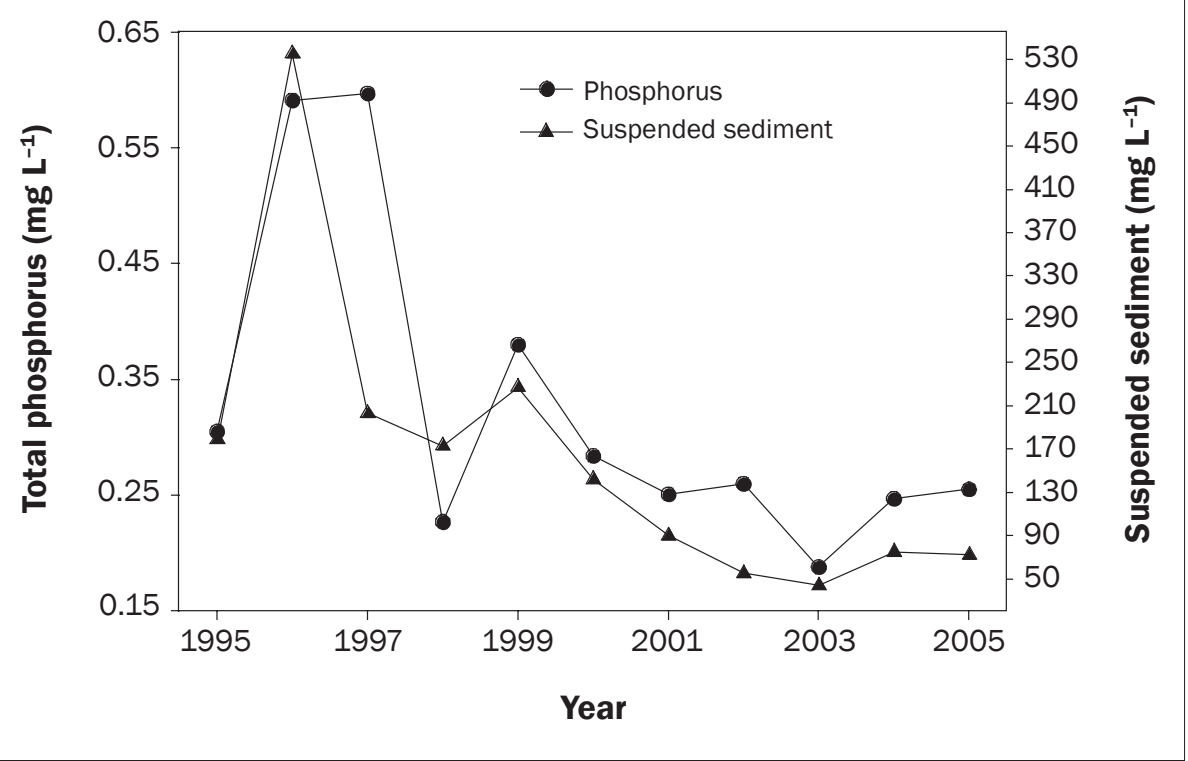

pared (Locke 2004). This enabled researchers to evaluate a number of factors within the context of a single system and an overall objective. A disadvantage in using a systems approach was the difficulty in assessing the impact of individual conservation measures. These issues are inherent to any watershed scale project. In order to address these difficulties, smaller, complementary studies conducted within the BLW were used to examine individual management practices. The value of this project to the CEAP effort

is its longevity, enabling researchers to monitor environmental changes in a dynamic watershed.

When data collection began in 1995 under MD-MSEA, 718 ha $(1,770 \mathrm{ac})$ of the watershed were cropped with cotton $(63.3 \%$ of cropped area), corn, and soybeans. Farmer practices in the watershed typically included disking the soil in the fall, preparing seedbeds just prior to planting, and cultivating during the growing season. During the period from 1995 to 2006, the 1996 farm bill's "Freedom

\section{Figure 7}

Chlorophyll $a$ and Secchi visibility depth for Beasley Lake (1995 to 2005).

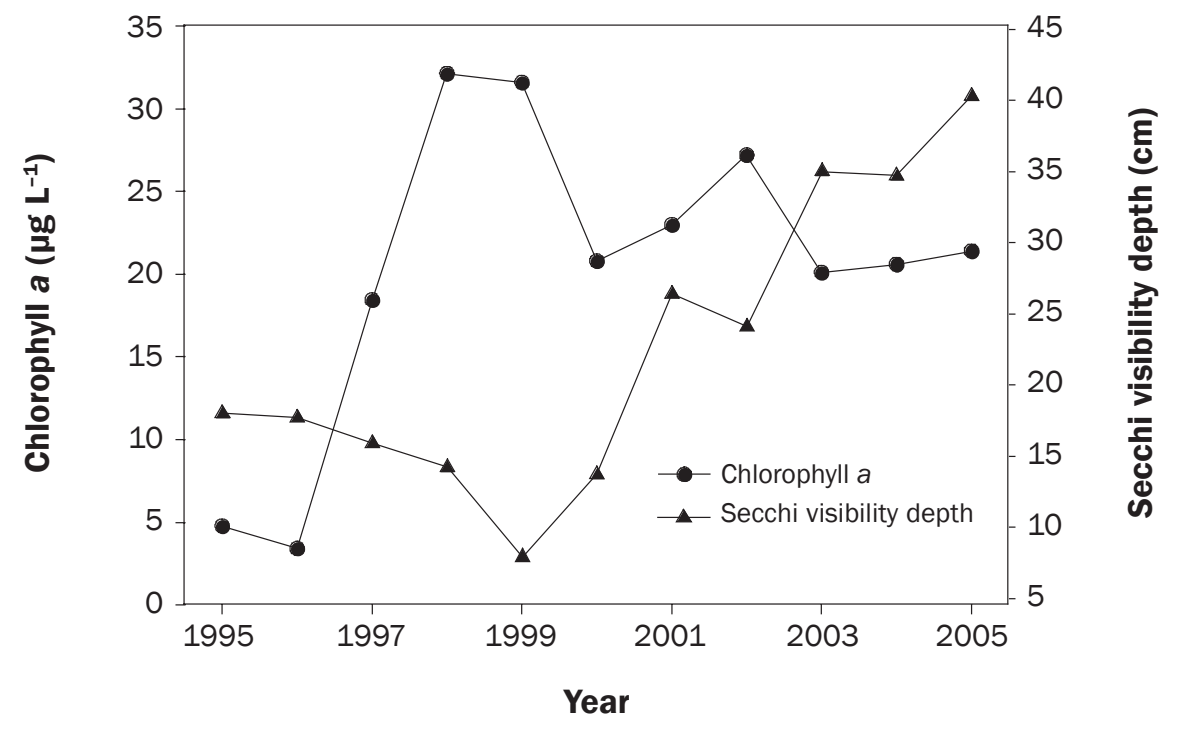




\section{Figure 8}

Biochemical activity in Beasley Lake, 2000 to 2003: (a) fluorescein diacetate (FDA) hydrolysis, (b) alkaline phosphatase activity, and (c) total organic carbon content.

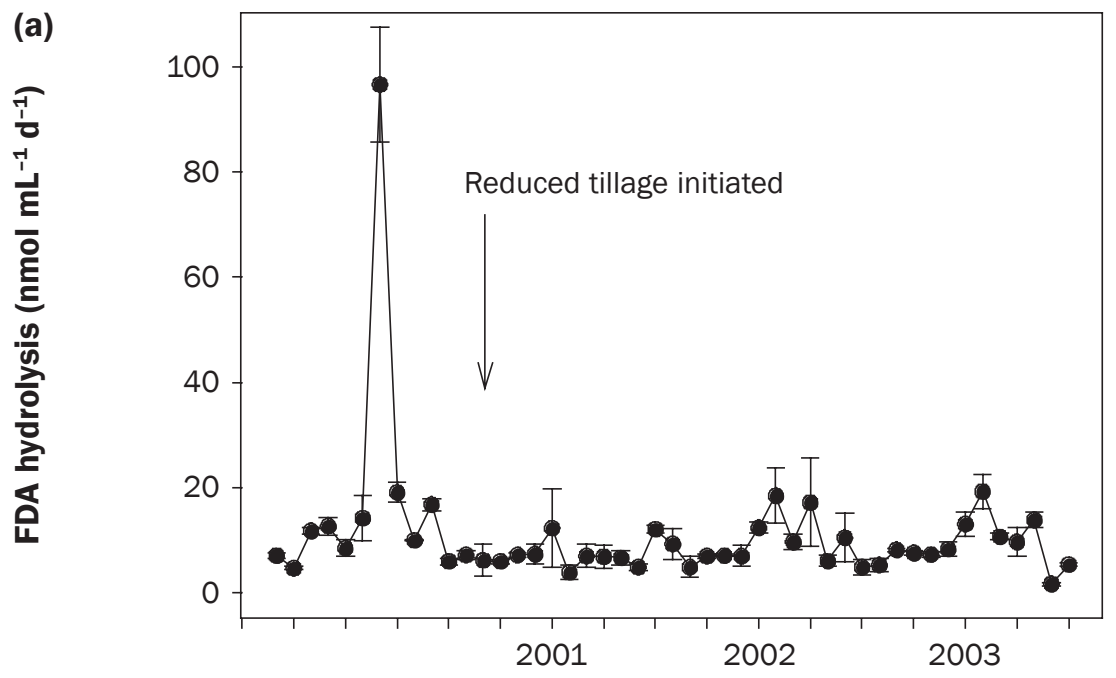

(b)

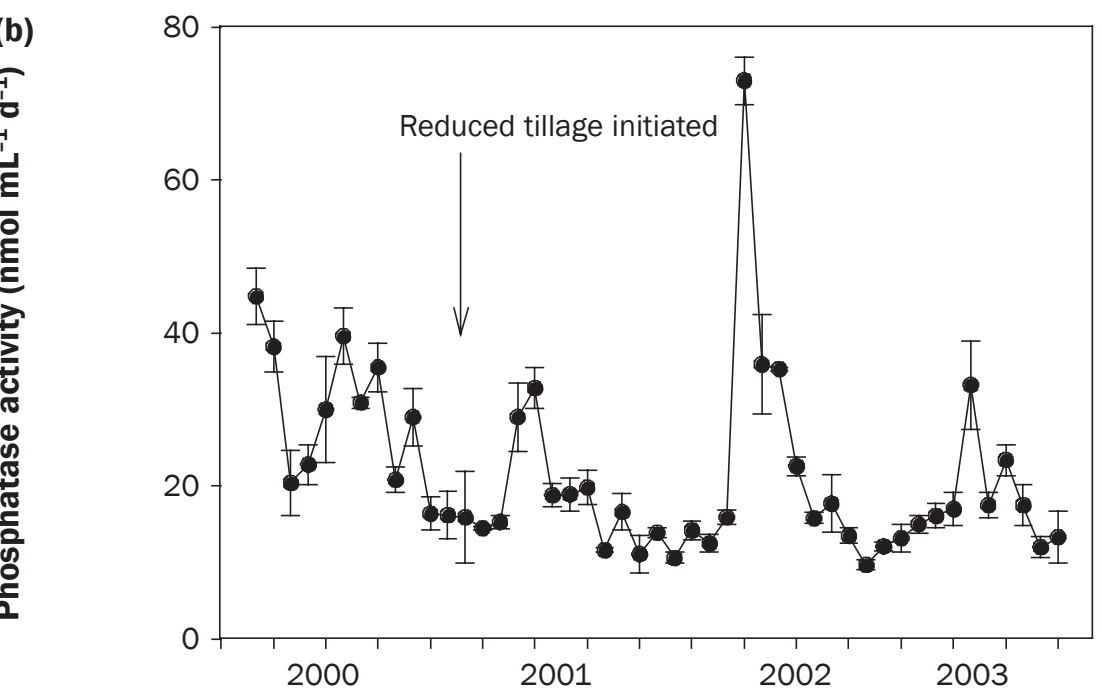

(c)

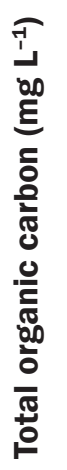

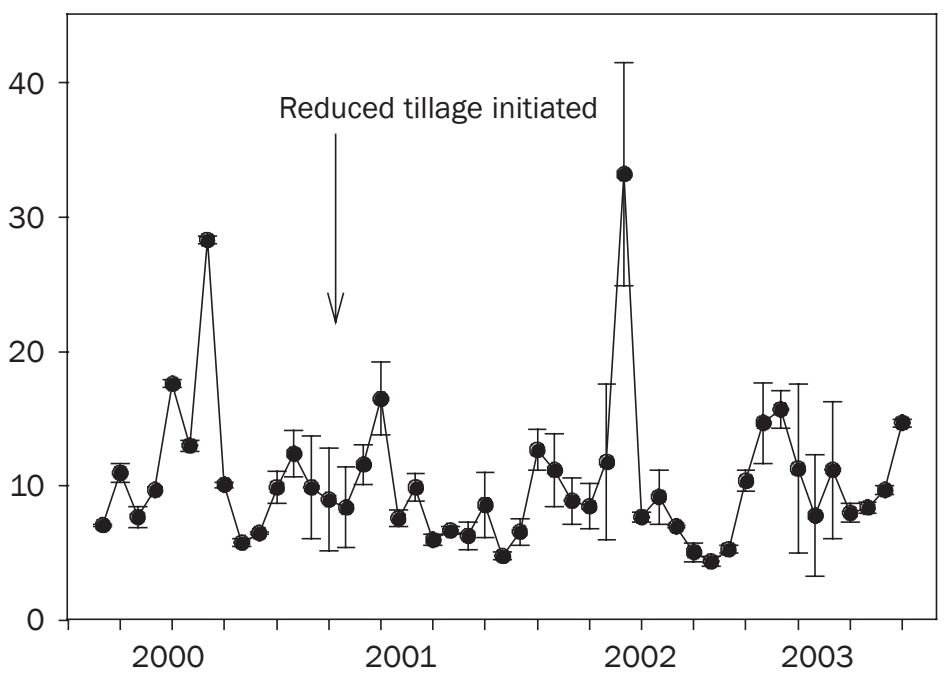

to Farm," advent of transgenic crop technology, and implementation of government sponsored conservation programs resulted in dramatic changes within BLW (figure 5). In 2001 and 2002, reduced tillage cotton and soybeans occupied most of the cultivated area, and from 2003 to 2006, reduced tillage soybeans were the dominant crop. In fall 2002, 113 ha $(280 \mathrm{ac})$ were removed from row crop production and planted to hardwood trees under the CRP. This trend is continuing throughout BLW.

Lake Water: Limnology. Analysis of water quality data from Beasley Lake over the past 11 years indicates that implementation of conservation tillage and CRP enrollment reduced sediment concentrations and improved water clarity, plankton growth, and fish stocks. Previously, suspended sediment had limited light availability which subsequently suppressed phytoplankton production. Implementing conservation practices resulted in water quality improvements that included a $70 \%$ decrease in suspended sediment concentration (figure 6), a $41 \%$ decrease in total phosphorus concentration (figure 6), and an increase of $97 \%$ in Secchi visibility (figure 7). Secchi visibility increased from a low of $13 \mathrm{~cm}$ (5 in) when the watershed was protected by slotted-pipes and grassed waterways to a high of $40 \mathrm{~cm}$ (16 in) following the implementation of conservation tillage and CRP (figure 7). As water clarity improved, chlorophyll a concentration, an indicator of primary productivity, increased 23\% (figure 7). Since phosphorus is typically associated with suspended sediments in agricultural runoff in the Mississippi Delta, reducing suspended sediments also reduced total phosphorus (figure 6).

Analysis of variance of the 47 monthly samples (triplicates) collected over four years indicated that the highest level $(p>0.001)$ of both enzyme (FDA and alkaline phosphatase) activities was observed in 2000, before conservation tillage practices were adopted in this watershed (after 2000) (figures 8a and $8 b$ ). Average FDA was $19.7 \mathrm{nmol} 24 \mathrm{~h}^{-1}$ in 2000 compared to $7.3,9.6$, and $9.3 \mathrm{nmol}$ $24 \mathrm{~h}^{-1}$ in 2001, 2002, and 2003, respectively $(p>0.0064)$. The post-conservation management levels of FDA activity are similar to levels of FDA hydrolysis observed after implementation of initial best management practices in 1997 to 1999 . Total phosphatase activity was $29.9 \mathrm{nmol} \mathrm{mL}^{-1} \mathrm{~h}^{-1}$ in 2000 compared to $18.4,23.4$, and 16.7 in 2001, 
Table 1

Summary of pesticide detections (adapted from Smith et al. 2007).

\begin{tabular}{|c|c|c|c|c|c|c|c|c|c|c|c|c|}
\hline \multirow[b]{2}{*}{ Pesticide } & \multicolumn{9}{|c|}{ Number of pesticide detections $\geq 0.1 \mathrm{ppb}$} & \multicolumn{3}{|c|}{ All detections (85 samples) } \\
\hline & 1998 & 1999 & 2000 & 2001 & 2002 & 2003 & 2004 & 2005 & Total & Mean (ppb) & sd & Max (ppb) \\
\hline Trifluralin & 0 & 0 & 0 & 0 & 0 & 0 & 0 & 0 & 0 & 0.005 & 0.010 & 0.069 \\
\hline Methyl parathion & 0 & 0 & 0 & 0 & 0 & 0 & 0 & 0 & 0 & 0.013 & 0.021 & 0.090 \\
\hline Alachlor & 0 & 0 & 1 & 0 & 0 & 0 & 0 & 0 & 1 & 0.005 & 0.014 & 0.110 \\
\hline Metolachlor & 1 & 7 & 6 & 1 & 0 & 0 & 3 & 0 & 18 & 0.234 & 1.140 & 10.046 \\
\hline Cyanazine & 2 & 2 & 8 & 4 & 0 & 0 & 0 & 0 & 16 & 0.087 & 0.212 & 1.339 \\
\hline Pendimethalin & 0 & 1 & 0 & 0 & 0 & 0 & 0 & 0 & 1 & 0.003 & 0.012 & 0.108 \\
\hline Fipronil & 0 & 0 & 0 & 0 & 0 & 0 & 0 & 0 & 0 & 0.004 & 0.003 & 0.012 \\
\hline Dieldrin & 0 & 0 & 0 & 0 & 0 & 0 & 0 & 0 & 0 & 0.003 & 0.005 & 0.029 \\
\hline pp'-DDE & 0 & 0 & 0 & 0 & 0 & 0 & 0 & 0 & 0 & 0.005 & 0.010 & 0.070 \\
\hline Bifenthrin & 0 & 0 & 0 & 0 & 0 & 0 & 0 & 0 & 0 & 0.012 & 0.018 & 0.076 \\
\hline$\lambda$-Cyhalothrin & 0 & 0 & 0 & 0 & 1 & 0 & 0 & 0 & 1 & 0.010 & 0.018 & 0.119 \\
\hline Total & 5 & 16 & 23 & 9 & 12 & 5 & 9 & 1 & 80 & & & \\
\hline
\end{tabular}

Notes: $\mathrm{ppb}=$ parts per billion. $\mathrm{sd}=$ standard deviation.

2002, and 2003, respectively $(p>0.0002)$. Alkaline phosphatase activity in plankton and other microorganisms is typically regulated by availability of inorganic phosphate. In Beasley Lake, phosphorus levels declined with the adoption of conservation management practices (figure 7). The inverse response of a reduction in phosphatase activity with decreased phosphate accumulation was observed.Although there were two major spikes in TOC content of the lake water during this period (July 2000 and December 2002) the yearly average TOC remained similar throughout the four years $(p=0.40)$. The highest spike in FDA hydrolytic activity coincided with the July 2000 spike in TOC. However, there was no real change in TOC following three years of implementation of conservation tillage practices in Beasley Lake. Increased dissolved organic matter stimulated phytoplankton blooms in a Florida estuary (Boyer et al. 2006). However, the effect of organic matter was not as great as addition of $\mathrm{N}$ or $\mathrm{P}$

Electrical conductivity and TOC of Beasley Lake water were highly correlated with both FDA and alkaline phosphatase (table 3), but neither suspended solids nor $\mathrm{pH}$ was correlated with either enzyme activity. Considering biological factors, FDA hydrolytic activity was highly correlated with most probable number estimates of total algae and chlorophyll a but not bacteria (table 3), indicating that phytoplankton may be the greatest contributor to this enzyme activity in this oxbow lake. On the other hand, alkaline phosphatase activity was highly correlated with chlorophyll $a$, but there was only a weak correlation with total bacteria, and it was not correlated with total algae most probable number estimates. Fluorescein diacetate hydrolytic activity may be a more suitable indicator of phytoplankton activity in oxbow lake water than alkaline phosphatase activity.

Improvement in primary productivity resulted in an improved sport fish population and represents one of the few times that best management practices installed throughout an agricultural landscape have been directly linked to ecological benefits (i.e., fish and wildlife). Catch per unit of effort, an index of stock abundance, increased by $85 \%$ from
4.7 to $31.3 \mathrm{~kg} \mathrm{hr}^{-1}$ (10 to $69 \mathrm{lb} \mathrm{hr}^{-1}$ ) over the course of the study (table 2). While the number of individual largemouth bass collected decreased during the study period, the total weight of bass increased by $87 \%$. This decrease in numbers and increase in standing stock makes sense considering the largemouth bass is the apex predator in the system. The catch of blue and redear sunfish increased both in number and weight. While some species of sediment-tolerant fish were reintroduced to the lake when the adjacent river flooded, the established population of largemouth bass was able to hold these species' numbers to a minimum.

Insecticides and Herbicides. Of the 80 pesticide detections $\geq 0.1 \mathrm{ppb}$ in surface water (table 1), 55\% occurred in 1998 to 2000 , $26 \%$ occurred in 2001 to 2002 , and $19 \%$ occurred in 2003 to 2005 (Smith et al. 2007).

Table 2

Fisheries characteristics for Beasley Lake in 1998 and 2004.

\begin{tabular}{lccc}
\hline & $\mathbf{1 9 9 8}$ & $\mathbf{2 0 0 4}$ & Percent change \\
\hline $\begin{array}{l}\text { Catch per unit of effort }\left(\mathrm{kg} \mathrm{h}^{-1}\right) \\
\text { Micropterus (largemouth bass) }\end{array}$ & 4.7 & 31.3 & $85 \%$ \\
$\quad$ & 48 & 21 & $-129 \%$ \\
$\quad$ Number & 6 & 46 & $87 \%$ \\
$\quad$ Weight (kg) & & & \\
Lepomis (bluegill) & 12 & 29 & $59 \%$ \\
$\quad$ Number & 19 & 54 & $65 \%$ \\
$\quad$ Weight (kg) & & &
\end{tabular}




\section{Table 3}

Pearson correlations of fluorescein diacetate (FDA) hydrolysis, alkaline phosphatase activity, and total organic carbon content (TOC) in Beasley Lake water samples, with other chemical, physical, and biological properties.

\begin{tabular}{|c|c|c|c|}
\hline Characteristic & FDA hydrolysis & Alkaline phosphatase activity & Total organic C \\
\hline \multirow[t]{2}{*}{ FDA hydrolysis } & $1.000 *$ & 0.2446 & 0.42155 \\
\hline & - & 0.0035 & $<0.0001$ \\
\hline \multirow[t]{2}{*}{ Alkaline phosphatase activity } & 0.2446 & 1.000 & 0.2638 \\
\hline & 0.0035 & - & 0.0018 \\
\hline \multirow[t]{2}{*}{ Total organic carbon content } & 0.42155 & 0.2638 & 1.0000 \\
\hline & $<0.0001$ & 0.0018 & - \\
\hline \multirow[t]{2}{*}{ Total solids } & -0.0432 & -0.0111 & -0.0474 \\
\hline & 0.6103 & 0.8956 & 0.5808 \\
\hline \multirow[t]{2}{*}{ Electrical conductivity } & 0.4492 & 0.2789 & 0.2866 \\
\hline & $<0.0001$ & 0.0008 & 0.0006 \\
\hline \multirow[t]{2}{*}{$\mathrm{pH}$} & 0.1506 & 0.1421 & 0.2518 \\
\hline & 0.0746 & 0.1003 & 0.0029 \\
\hline \multirow[t]{2}{*}{ Total algae } & 0.3030 & -0.01457 & -0.2913 \\
\hline & 0.0006 & 0.8713 & 0.0009 \\
\hline \multirow[t]{2}{*}{ Total bacteria } & -0.2107 & -0.2511 & -0.2395 \\
\hline & 0.0765 & 0.0331 & 0.0475 \\
\hline \multirow[t]{2}{*}{ Chlorophyll a } & 0.3960 & 0.2051 & -0.0597 \\
\hline & $<0.0001$ & 0.0185 & 0.4980 \\
\hline
\end{tabular}

* Pearson correlation coefficients and $p>r$.

Across the entire sampling period, herbicides accounted for $85 \%$ of the pesticide detections. These observations reflect the trends in crops grown and management practices used in the watershed during those periods. Prior to 2001, conventional tillage was employed in cropped areas throughout BLW, and the majority of the cropped area was in cotton production (figure 5). In 2001 to 2002, reduced-tillage cotton and soybean occupied most of the watershed. From 2003 to the present, the north side of Beasley lake was in trees under CRP, with the balance of the watershed in predominantly reduced-tillage soybeans. Thus, the number of lake water pesticide detections $\geq 0.1 \mathrm{ppb}$ was progressively reduced as watershed practices transitioned from conventional tillage to reduced-tillage to reduced-tillage plus CRP (Smith et al. 2007). Of the pesticide detections $\geq 0.1$ ppb from 2001 to 2005 (table 1), almost onethird were legacy pesticides (e.g., DDT) and not those in current use.
The balance of pesticide detections reflected usage due to changes in crops grown from year to year. Increased detections of atrazine and metolachlor were attributed to increased use in corn (atrazine and metolachlor) and soybean (metolachlor). Metolachlor often is applied at the same time as atrazine in the watershed under corn production, and the dynamics of metolachlor appearance and dissipation followed the same dynamics as atrazine (Zablotowicz et al. 2006). Decreased metolachlor detections after 2000 also may have been due to a conversion to the s-metolachlor form. The s-form of metolachlor has greater herbicidal activity and application rates can be reduced to about $35 \%$ of that needed for the previous metolachlor mixture. Also, increased use of glyphosate-resistant crops probably contributed to a decline in pre-emergence herbicides. Cyanazine was phased out, resulting in no detections after 2001. Low insecticide detections in lake water were attributed to their relatively short persistence and low water solubility.

Other reports of some of these pesticides in Beasley Lake water can be found elsewhere Zablotowicz et al. (2004, 2006), and they corroborate these results. In particular, fluometuron was evaluated by Zablotowicz et al. (2004, 2006). Fluometuron was widely used in cotton production in the Mississippi Delta. However, it's use decreased with the adoption of glyphosate resistant cotton. The occurrence of fluometuron in Beasley Lake water is summarized in figure 9. Maximum concentrations observed from 1996 to 2003 ranged from 2.1 to $5.7 \mu \mathrm{g} \mathrm{L}^{-1}$ (2.1 to 5.7 $\mathrm{ppb})$. However, once glyphosate resistant cotton was planted in the watershed (post 2001), detection maximums declined. In years when fluometuron was applied, fluometuron was detected in $66 \%$ to $100 \%$ of the samples tested. The highest fluometuron concentrations were typically observed in June, about two months after cotton planting. The fluometuron metabolite, DMF, also was found in all three lakes when fluometuron was detected (Zablotowicz et al. 2004). Corn replaced cotton on about $30 \%$ of the crop land in 1998, and maximum concentrations of fluometuron were about half that observed in 1996 and 1997. During 1998 and 1999, rainfall in the delta during June and July was about 40\% that of 1996 and 1997, which resulted in substantially reduced runoff. Reduced concentrations of fluometuron in Beasley Lake after 2000 were associated with greater use of glyphosate-resistant cotton and correspondingly less need for soil-applied fluometuron herbicide.

Field and Wetland Evaluations: Wetland and Drainage Ditch Studies. Natural and constructed wetlands located between agricultural lands and receiving water bodies may enhance agrichemical processing and retention of agrichemicals, but relationships between wetland characteristics and mechanisms involved in trapping and processing chemicals are not well documented. Several MD-MSEA studies evaluated physical, chemical, and microbiological characteristics of soils in the large, natural riparian area in the BLW (figure 2) and demonstrated the potential for contributing to pesticide dissipation. Activities of the soil enzymes esterase, dehydrogenase, and aryl acylamidase, and FDA hydrolytic activity were significantly greater in riparian soil compared to cropland soil (Zablotowicz et al. 2001; Locke et 
al. 2003), with increasingly higher levels of enzymes in soils closer to the lake. Higher levels of enzymes were associated with increasing moisture, organic carbon, and clay contents. Similar trends were observed for total bacteria, gram negative bacteria, and fungi populations and activities.

The potential for natural forest riparian soils to influence fluometuron herbicide dissipation also was evaluated (Zablotowicz et al. 2001; Locke et al. 2003; and Shankle et al. 2004). Generally, fluometuron degradation was more rapid in riparian soils as compared to adjacent cropland soils. This was attributed to higher microbial activities and populations (degradation) and increased organic carbon and clay content (sorption). However, fluometuron degradation was inhibited under anaerobic conditions.

Constructed wetlands offer promise for removal of nonpoint source contaminants such as herbicides from agricultural runoff. A constructed wetland in BLW was used for field and laboratory studies to assess the potential of soils and wetland plants to mitigate detrimental effects of pesticide runoff on downstream water resources (Moore et al. 2007 a, 2007b; Weaver et al. 2004; Bouldin et al. 2007). Weaver et al. (2004) reported differential effects of flooding on the persistence of the herbicides atrazine and fluometuron mixed with soil from the recently established constructed wetland. Fluometuron was much more persistent under flooded versus 12\% air filled pore space incubation, while atrazine was rapidly incorporated into soil bound components in both circumstances. In a simulated storm runoff experiment to evaluate pesticide fate in the BLW constructed wetland, water dosed with diazinon was added at the wetland entrance for $4 \mathrm{~h}$, and diazinon was monitored for the subsequent 55 days (Moore et al. 2007a). Over 40\% of the pesticide was measured in plants within the wetland, demonstrating the contribution of vegetation to pollutant processing.

Results from these studies indicate that preservation and maintenance of natural forested riparian zones should be an important management practice to reduce non-point pollution of surface waters by agrochemicals. Further, these studies suggest that wetlands constructed in marginal areas can be useful in mitigating agricultural runoff and associated pollutants.

Drainage ditches are common elements of agricultural landscapes, and they repre-

\section{Figure 9}

Fluometuron evaluations in Beasley Lake, 1996 to 2003: (a) mean and standard deviation of maximum fluometuron concentrations and (b) number of positive fluometuron detections.
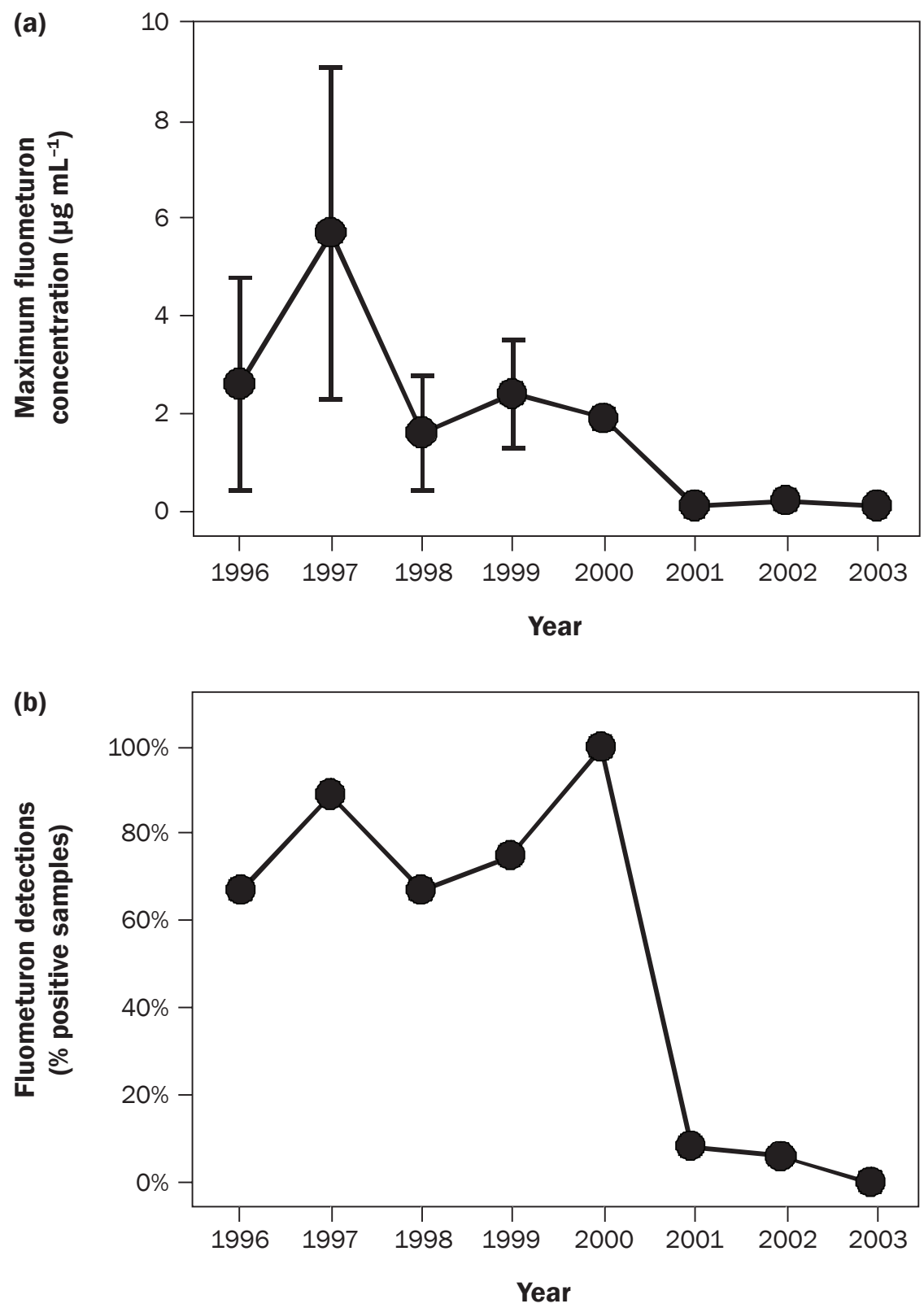

sent ecosystems that may be managed to improve water quality. Moore et al. (2001) evaluated the potential of a $50-\mathrm{m}(54.7-\mathrm{yd})$ segment of an agricultural drainage ditch in BLW to mitigate movement of atrazine and lambda-cyhalothrin in a simulated storm runoff event. One hour following initiation of simulated runoff, $37 \%$ and $2 \%$ of the atrazine concentrations measured in the ditch were associated with water and sediment, respectively, while respective percentages of lambda-cyhalothrin were
$12 \%$ and $1 \%$. Percentage concentrations of atrazine and lambda-cyhalothrin associated with plants at one hour were $61 \%$ and $87 \%$, respectively. Therefore, plants serve as an important site for pesticide sorption during runoff events. Aqueous concentrations of both pesticides decreased to levels which would not elicit non-target toxicological effects by the end of the 50-m portion of the drainage ditch. This research provides fundamental answers concerning the capability of vegetated agricultural drainage 
ditches to mitigate pesticide-associated storm water runoff.

Edge-of-Field Conservation Management Effects on Quality of Water Leaving the Field. Vegetated buffer strip areas at edges of fields slow movement of sediments and contaminants in surface runoff, but little is reported about the fate of herbicides trapped in those areas. Mississippi Delta Management Systems Evaluation Area project laboratory studies assessed the dissipation of metolachlor herbicide in vegetative buffer strip soils (Staddon et al. 2001). The half life of metolachlor in the buffer strip soil was 10 days compared to 23 days in soil from an adjacent field. Buffer strip soils also had a higher capacity to bind metolachlor. Faster herbicide degradation and higher binding capacity in buffer strip soils were attributed to a more active microbial population and increased organic carbon. This study suggests that increased retention and enhanced degradation of metolachlor as it passes through the vegetative strips may limit further transport.

In another BLW study, combinations of edge-of-field practices, such as grade-control, vegetative barrier, and tile drainage practices were assessed as to their ability to reduce sediment and pesticide delivery from agricultural fields (Smith et al. 2002). Switchgrass (Panicum virgatum) barriers surrounding grade control pipes survived winter ponding by a slotted-board-riser, and tile drains located under the thalweg of surface water furrows prevented the development of problematic wet spots and facilitated farming operations on a silty clay soil. This innovative combination of practices might achieve much of the sediment-reduction benefits of a small permanent impoundment without taking more land out of production than an ordinary grade control pipe. However, effects of these practices on mitigation of pesticides in runoff were not significant in the early stages of the study in BLW (Smith et al. 2002) because initially the vegetative barriers were not well established (low plant density, thus, poor sediment trapping/retention).

Agronomic Management Effects on Runoff. Utilizing genetically engineered Bt cotton reduced the volume of pyrethroid insecticides applied (Cullum and Smith 2001). The number of detections of pyrethroids in runoff from Bt cotton was significantly less than from non-Bt cotton areas, but no difference in organophosphate detections was observed between the two management treatments.
Although both pyrethroid and organophosphate were detected in runoff from both $\mathrm{Bt}$ and non-Bt cotton fields, concentrations were low, indicating minimal detrimental environmental effects.

Soil Assessments. Precision agriculture practices require detail and certainty about the spatial variability of soils. Mississippi Delta Management Systems Evaluation Area project studies characterized field-scale spatial variability of soil properties that influence herbicide fate in the soil environment and determined relationships between soil properties (soil organic carbon, $\mathrm{pH}$, texture) and weed populations (Gaston et al. 2001; Locke et al. 2003). Weeds controlled with preemergence herbicides were more abundant, and herbicide sorption was higher in areas that had higher organic matter content and higher clay content. In contrast, low organic matter and sandier areas often produced no weeds and low herbicide sorption. Results suggest that more uniform control of weeds might be achieved by varying pre-emergence herbicide application and that acceptable weed control might be achieved with lower rates of herbicide application in certain areas.

No results are available concerning newly established CRP areas in BLW. Soils are being sampled periodically and evaluated for chemical, physical, and biological parameters. This will continue over a multi-year period.

Modeling. Results of model validation showed satisfactory model performance, with an E value of 0.81 for runoff and 0.52 for sediment (Moriasi et al. 2007). Simulating existing conditions in the watershed showed that the 8 -year annual average runoff was $625.6 \mathrm{~mm}$ (24.6 in) and annual average soil erosion was $3.29 \mathrm{Mg} \mathrm{ha}^{-1}\left(1.5 \mathrm{t} \mathrm{ac}^{-1}\right)$ over the entire watershed. In general, less erosion occurred when soybeans were grown than when cotton was grown. Based on field management records, there was less cultivation performed in soybean fields than in cotton fields, with reduced tillage implemented in most of the soybean fields after year 2000 . Simulations of various management practices illustrated the capability of AnnAGNPS to assess the impact of alternative management practices. The application of the model demonstrated that the utilization of various fields with no-tillage practices or as grassland areas could reduce sediment loadings to a range of $15 \%$ to $69 \%$ of the existing condition. Model simulations showed that converting all cropland to no-tillage soybeans would reduce sediment loading by $77 \%$, while converting all cropland to no-tillage cotton would reduce sediment loading by $64 \%$. An appropriate conservation practice can be determined through watershed simulation that reduces sediment to an acceptable level and still remains an economical system for the agricultural producers.

Additional conservation practices that incorporate riparian buffers could further reduce sediment loads from the watershed. Combining the technology of the REMM (Lowrance et al. 2000) and AnnAGNPS models can provide additional information on the effectiveness of conservation practices within the watershed to assess riparian buffer effectiveness in filtering nutrients (Yuan et al. 2007).

\section{Summary and Conclusions}

Integrated research studies that address the impacts of conservation management practices at a watershed scale in support of CEAP were successfully implemented in the BLW. This research is a valuable and unique component of the national CEAP effort by considering the effects of conservation practices on lake water ecosystems as well as within agricultural fields. This assessment included studies that demonstrated the effects of individual as well as combinations of conservation practices within the watershed. Understanding these effects is critical to action agencies, such as the USDA Natural Resources Conservation Service, in their implementation of conservation programs throughout the United States.

This paper provides information about changes in pesticide and nutrient occurrence and concentrations in Beasley Lake water over many years that parallels changes in watershed management, particularly for crops grown and tillage operations. In order to provide a complete understanding of watershed management effects on pesticide and nutrient dynamics, lake water data were combined with data from current studies in the BLW concerning pesticide and nutrient reductions from edge-of-field structural and cultural (vegetative) management strategies. By combining watershed pesticide and nutrient dynamics information with other BLW water quality information (e.g., nutrients, dissolved oxygen, turbidity, chlorophyll, suspended sediments), the goal of quantifying the beneficial effects of watershed conserva- 
tion management practices on the ecological integrity of the watershed is attainable.

Results of these studies indicated that combinations of conservation practices applied on a watershed basis significantly reduced nonpoint source agricultural pollutants. Furthermore this reduction was of sufficient magnitude to improve the productivity of the lake. There was fundamental improvement in the primary producers (phytoplankton) benefiting from the conservation practices. Additionally, benefits to the primary producers had a positive impact on the higher trophic levels of the lake as indicated by improved standing stocks of the top predators in the system.

While the complexity and longevity of the project make analysis somewhat difficult, this very complexity makes it possible to examine the cumulative benefits of different practices as they were implemented over time. Initial conservation practices, based on structures and grassed waterways, produced limited reductions in sediments entering the lake. However, as additional practices were implemented, pollutants declined to a point that allowed measurable improvements in lake productivity.

A synopsis of research findings in BLW are as follows: Combinations of conservation practices significantly reduced non-point pollutants in agricultural runoff. While structure-based edge-of-field conservation practices were minimally effective, addition of within field practices resulted in improvements to water quality. Reductions in agricultural runoff resulted in lake water quality improvements that were sufficiently large to improve the lake's primary productivity. Improvements in primary productivity resulted in the development of a sustainable sports fishery.

Based on results from this project, future research should be focused on the effects of innovative conservation practices, on refining the individual contribution each practice makes in reducing nonpoint source pollutants, and using modeling tools to make reasonable predictions as to the effects of individual and combinations of practices.

\section{Acknowledgements}

Thanks to Darlene Wilcox for preparing maps, Frank Gwin and Wade Steinriede for accumulating management information, Richard Lizotte for numerous sampling runs, and Richard Rebich for runoff sampling data. These are but a few of the many personnel who have contributed to the success of the MD-MSEA and CEAP projects, and thank you to those unnamed as well.

\section{References}

American Public Health Association. 1992. Standard methods for the examination of water and waste water. 18th ed. American Public Health Association Washington.

Bennett, E.R., M.T. Moore, C.M. Cooper, and S. Smith Jr. 2000. Method for the simultaneous extraction and analysis of two current-use pesticides, atrazine and $\lambda$ cyhalothrin, in sediment and aquatic plants. Bulletin of Environmental and Contamination Toxicology 64:825-833.

Bingner, R.L., and F.D. Theurer. 2001. AnnAGNPS Estimating sediment yield by particle size for sheet \& rill erosion. In Proceedings of the Sediment: Monitoring, Modeling, and Managing, 7th Federal Interagency Sedimentation Conference, I-1 - I-7. Reno, NV, 25-29 March 2001.

Bouldin J.L., J.L. Farris, M.T. Moore, S. Smith Jr., and C.M. Cooper. 2007. Evaluation of diazinon toxicity in constructed wetlands using biomarkers from in situ Corbicula fluminea and laboratory biomonitoring. Archives of Environmental and Contamination Toxicology 53:174-182.

Boyer, J.N. 2006. Shifting N and P limitation along a northsouth gradient of mangrove estuaries in South Florida. Hydrobiologia 569:167-177.

Boyer, J.N., S.K. Dailey, P.J. Gibson, M.T. Rodgers, and D Mir-Gonzalez. 2006. The role of dissolved organic matter bioavailability in promoting phytoplankton blooms in Florida Bay. Hydrobiologia 569:71-85.

Cooper, C.M., S. Smith Jr., and M.T. Moore. 2003. Surface water, ground water, and sediment quality in three oxbow lake watersheds in the Mississippi Delta agricultural region: Pesticides. International Journal of Ecology and Environmental Sciences 29:171-184.

Cullum, R.F., and M.A. Locke. 2007. Water quality evaluations comparing cultivated soybean fields with recently converted Conservation Reserve Areas. In 2007 Soil and Water Conservation Society Annual Conference Final Program and Abstract Book, 51. Tampa, FL. Ankeny, IA SWCS.

Cullum, R.F., S.S. Knight, C.M. Cooper, and S. Smith Jr. 2003. Best Management Practices Effects on Water Quality in Oxbow Lakes within the Mississippi Delta. American Society Agricultural Engineers International Meeting. Las Vegas, NV, July 27-30. ASAE Paper \# 032163. p. 1-13.

Cullum, R.F., and S. Smith Jr. 2001. BT cotton in Mississippi Delta Management Systems Evaluation Area: Insecticides in runoff 1996-1999. In The Mississippi Delta Management Systems Evaluation Areas Project, 1995-1999, ed. R.A. Rebich and S.S. Knight. Mississippi Agricultural and Forestry Experiment Station Information Bulletin 377:91-99.

Dendy, F.E. 1981. Sediment yield from a Mississippi Delta cotton field. Journal of Environmental Quality 10:482-486.

Gaston, L.A., M.A. Locke, R.M. Zablotowicz, and K.N. Reddy. 2001. Spatial variability of soil properties and weed populations in the Mississippi Delta. Soil Science Society of American Journal 65:449-459.
Hill, B.H., A.T. Herlihy, P.R. Kaufmann, S.J. DeCelles, and M.A.Vander Borgh. 2003. Assessment of streams of the eastern United States using a periphyton index of biotic integrity. Ecological Indicators 2:325-338.

Knight, S.S., C.M. Cooper, and B. Cash. 2001a. Effects of agricultural system practices on Mississippi Delta MSEA lake water quality. In The Mississippi Delta Management Systems Evaluation Areas Project, 1995-1999, ed. R.A Rebich and S.S. Knight. Mississippi Agricultural and Forestry Experiment Station Information Bulletin 377:128-138.

Knight, S.S., C.M. Cooper, and T. Welch. 2001b. Fishery evaluation of Mississippi Delta management systems evaluation area oxbow lakes. In The Mississippi Delta Management Systems Evaluation Areas Project, 1995 1999, ed. R.A. Rebich and S.S. Knight. Mississippi Agricultural and Forestry Experiment Station Information Bulletin 377:139-143.

Knight, S.S., and T.D. Welch. 2004. Evaluation of watershed management practices on oxbow lake ecology and water quality. In Water Quality Assessments in the Mississippi Delta: Regional Solutions, National Scope, ed. M.T. Nett, M.A. Locke, and D.A. Pennington, 119-133. ACS Symposium Ser. 877.

Locke, M.A. 2004. Mississippi Delta Management Systems Evaluation Areas: Overview of water quality issues on a watershed scale. In Water Quality Assessments in the Mississippi Delta: Regional Solutions, National Scope, ed. M.T. Nett, M.A. Locke, and D.A. Pennington, 1-15. ACS Symposium Ser. 877.

Locke, M.A., R.M. Zablotowicz, and L.A. Gaston. 2003. Environmental fate of fluometuron in a Mississippi Delta lake watershed. In Terrestrial Field Dissipation Studies: Purpose, Design, and Interpretation, ed. E.L. Arthur, A.C. Barefoot, and V.E. Clay, 206-225. ACS Symposium Series 842 .

Lowrance, R.R., L.S. Altier, R.G. Williams, S.P. Inamdar, D.D. Bosch, R.K. Hubbard, and D.L. Thomas. 2000. The riparian ecosystem management model. Journal of Soil and Water Conservation 55(1):27-36.

McDowell, L.L., G.H.Willis, and C.E. Murphree. 1984. Plant nutrient yields in runoff from a Mississippi Delta watershed. Transactions of the ASAE 27:1059-1066.

Moriasi, D.N., J.G. Arnold, M.W. Liew, R.L. Bingner, R.D. Harmel, and T.Veith. 2007. Model evaluation guidelines for systematic quantification of accuracy in watershed simulations. Transactions of the ASABE 50(3):885-900.

Moore, M.T., E.R. Bennett, C.M. Cooper, S. Smith Jr., F.D. Shields Jr., C.D. Milam, and J.L. Farris. 2001. Transport and fate of atrazine and lambda-cyhalothrin in an agricultural drainage ditch in the Mississippi Delta, USA Agriculture, Ecosystems, and Environment 87:309-314.

Moore M.T., C.M. Cooper, S. Smith Jr., R.F. Cullum, S.S. Knight, M.A. Locke, and E.R. Bennett. 2007a. Diazinon mitigation in constructed wetlands: Influence of vegetation. Water, Air, and Soil Pollution 184:313-321.

Moore, M.T., R.E. Lizotte Jr., and S. Smith Jr. 2007b. Toxicity evaluation of diazinon contaminated leaf litter. Bulletin of Environmental and Contamination Toxicology 78:158-161.

Murphree, C.E., and K.C. McGregor. 1991. Runoff and sediment yield from a flatland watershed in soybeans. Transactions of the ASAE 34(2):407-411.

Nett, M.T., M.A. Locke, and D.A. Pennington, ed. 2004. Water quality assessments in the Mississippi Delta: Regional solutions, national scope. ACS Symposium Series 877, Oxford University Press. 
Rebich, R.A. 2004. Suspended sediment and agrochemicals in runoff from agricultural systems in the Mississippi Delta: 1996-2000. In Water Quality Assessments in the Mississippi Delta: Regional Solutions, National Scope, ed. M.T. Nett, M.A. Locke, and D.A. Pennington, 104118. ACS Symposium Ser. 877.

Rebich, R.A., and S.S. Knight, ed. 2001.The Mississippi Delta Management Systems Evaluation Areas Project, 1995 1999. Mississippi Agricultural and Forestry Experiment Station Information Bulletin 377.

Regel, R.H., J.M. Ferris, G.G. Ganf, and J.D. Brookes. 2002 Algal esterase activity as a biomeasure of environmental degradation in a freshwater creek. Aquatic Toxicology 59:209-223

Shankle, M.W., D.R. Shaw, W.L. Kingery, and M.A. Locke. 2004. Fluometuron adsorption and degradation in soil influenced by best management practices. In Water Quality Assessments in the Mississippi Delta: Regional Solutions, National Scope, ed. M.T. Nett, M.A. Locke, and D.A. Pennington, 164-178. ACS Symposium Ser. 877.

Smith, Jr., S., and C.M. Cooper. 2004. Pesticides in shallow groundwater and lake water in the Mississippi Delta MSEA. In Water quality assessments in the Mississippi Delta: Regional solutions, national scope. ed. M.T. Nett, M.A. Locke, and D.A. Pennington, 91-103. ACS Symposium Ser. 877

Smith, Jr., S., C.M. Cooper, R.E. Lizotte, M.A. Locke, and S.S. Knight. 2007. Pesticides in lake water in the Beasley Lake Watershed, 1998-2005. International Journal of Ecology and Environmental Sciences 33:61-71.

Smith Jr., S., S.M. Dabney, and C.M. Cooper. 2002 Vegetative barriers affect surface water quality leaving edge-of-field drainage pipes in the Mississippi Delta. In Total Maximum Daily Load (TMDL) Environmental Regulations, 454-465. American Society of Agricultural Engineers, St. Joseph, MI.

Staddon, W.J., M.A. Locke, and R.M. Zablotowicz. 2001 Microbiological characteristics of a vegetative buffer strip soil and degradation and sorption of metolachlor. Soil Science Society of American Journal 65:1136-1142.

Weaver, M.A., R.M. Zablotowicz, and M.A. Locke. 2004 Laboratory assessment of atrazine and fluometuron degradation in soils from a constructed wetland. Chemosphere 57(8):853-862

Willis, G.H.,L.L.McDowell, C.E.Murphree,L.M.Southwick, and S.S. Smith. 1983. Pesticide concentrations and yields in runoff from silty soils in the Lower Mississippi Valley. Journal of Agricultural Food Chemistry. 31:1171-1177.

Yuan, Y., R.L. Bingner, R.G. Williams, R.R. Lowrance, D.D Bosch, and J.M. Sheridan. 2007. Integration of the models of AnnAGNPS and REMM to assess riparian buffer system for sediment reduction. International Journal of Sediment Research 22(1):60-69.

Zablotowicz, R.M., M.A. Locke, L.J. Krutz, R.N. Lerch, R.E. Lizotte, S.S. Knight, R.E. Gordon, and R.W. Steinriede. 2006. Influence of watershed system management on herbicide concentrations in Mississippi Delta oxbow lakes. Science of the Total Environment 370:552-560.

Zablotowicz, R.M., M.A. Locke, R. Lerch, and S.S. Knight. 2004. Dynamics of herbicide concentrations in Mississippi Delta oxbow lakes and the role of planktonic microorganisms in herbicide metabolism. In Water Quality Assessments in the Mississippi Delta: Regional Solutions, National Scope, ed. M.T. Nett, M.A. Locke, and D.A. Pennington, 134-149. ACS Symposium Ser. 877.
Zablotowicz, R.M., M.A. Locke, W.J. Staddon, M.W. Shankle, D.R. Shaw, and W.L. Kingery. 2001. Microbiological characteristics of a Mississippi Delta forested riparian zone. In The Mississippi Delta Management Systems Evaluation Areas project, 1995-1999, ed. R.A. Rebich and S.S. Knight. Mississippi Agricultural and Forestry Experiment Station Information Bulletin 377:218-222. 